\title{
Pandangan Mahasiswa terhadap Hambatan pada Pelaksanaan Skill Lab di Fakultas Kedokteran Universitas Andalas
}

\author{
Hardisman $^{*}$ dan Yulistini ${ }^{* *}$ \\ *Bagian Ilmu Kesehatan Masyarakat \& Kedokteran Komunitas, \\ ${ }^{* *}$ Bagian Mikrobiologi, Fakultas Kedokteran Universitas Andalas
}

\begin{abstract}
Background: Skill lab is a clinical skill training using model and simulation, which is very important in the learning process to develop clinical skill competencies of medical students. Through the process, the next step of learning on real patients will be safer and more effective.

Objective: The study was conducted to explore learning barriers of medical students in the skill lab training to obtain experiences and competencies.

Method: A qualitative study was conducted to explore the problems using in-depth interview as method of data collection. Thematic analysis was used to analyze the data. The respondents of the study were 46 medical students in semester $V$ and VII in the Faculty of Medicine, Andalas University.

Result and Discussion: The main barriers that the students faced were clinical instructor factors, such as late attendance and replacement time with shorter allocation. Due to these factors, the students could not obtain optimal learning process, supervision and required competencies. Other factors such as lack of simulation model and limited time had also significant impact.

Conclusion: Learning barriers of skill lab training were caused by multi factors. Therefore, systematic arrangement, facility and assessment, and the quality of instructors' performance need to be improved.
\end{abstract}

Keywords: skill lab, barriers and competencies

\section{ABSTRAK}

Latar Belakang: Skill lab merupakan metode latihan keterampilan klinis dengan menggunakan model atau simulasi yang menjadi sarana yang sangat penting untuk menumbuhkan keterampilan lebih awal pada mahasiswa. Melalui proses pembelajaran ini, proses pembelajaran tahap lanjut pada pasien menjadi lebih aman dan efektif.

Tujuan:Penelitian ini dilakukan untuk mengetahui hambatan dalam pelaksanaan skill lab dalam mendapatkan pengalaman belajar dan pencapaian kompetensi yang diharapkan bagi mahasiswa.

Metode: Penelitian dilakukan dengan desain kualitatif untuk menggali permasalahan lebih mendalam dengan metode pengumpulan data melalui wawancara mendalam, kemudian data diolah dan dianalisa secara tematik. Responden adalah 46 orang mahasiswa semester V dan VII di Fakultas Kedokteran Universitas Andalas.

Hasil dan Pembahasan: Hambatan dalam pelaksanaan skill lab yang dialami mahasiswa terutama disebabkan oleh kehadiran dosen instruktur yang tidak tepat waktu ataupun penggantian jadwal dengan alokasi waktu yang tidak sesuai. Akibatnya mahasiswa tidak mendapatkan pembelajaran, praktik keterampilan, bimbingan dan pencapaian kompetensi yang diharapkan. Faktor-faktor lain juga berperan seperti kurangnya peralatan dan alokasi waktu.

Kesimpulan:Hambatan pada pelaksanaan skill lab disebabkan oleh multi faktor. Oleh karena itu untuk mengatasi hambatan ini harus dilakukan penataan sistem, mencukupi fasilitas dan penataan beban kerja dosen.

Kata Kunci: Skill lab, hambatan, dan kompetensi

Korespondensi: hardisman@fk.unand.ac.id 


\section{PENDAHULUAN}

Keterampilan klinis (clinical skills) pada profesi kedokteran merupakan hal yang mutlak dibutuhkan. Keterampilan tersebut merupakan kecakapan motorik yang dilandasi oleh pengetahuan dan sikap afektif yang baik. Pelayanan kedokteran tidak dapat dijalankan dengan baik dan optimal jika hanya mengandalkan pemahaman keilmuan tanpa adanya keterampilan tersebut. Bahkan, keterampilan klinis bagi dokter harus terinternalisasi dalam dirinya, sehingga dalam melakukan tindakan dan penatalaksanaan kasus yang sesungguhnya terjadi otomatis karena keilmuan dan keterampilan tersebut telah menyatu (embedded) dengan perilaku profesionalnya. ${ }^{1.3}$ Untuk mencapai kemampuan klinis yang baik tersebut sangat diperlukan latihan yang optimal bagi calon dokter selama menjalani pendidikan, baik dari segi kualitas ataupun kuantitas. ${ }^{2,3}$

Proses belajar dalam mematangkan kemampuan klinis dengan real patients akhir-akhir ini menjadi tantangan sendiri bagi mahasiswa kedokteran dan profesi kesehatan lainnya karena adanya perubahan paradigma dalam pelayanan kesehatan dari sisi etika, hukum, dan pendayagunaan teknologi kesehatan. ${ }^{4}$ Pada satu sisi pelayanan kepada masyarakat (pasien) haruslah pelayanan yang aman (safe) berkualitas (high quality), tapi pada sisi lainnya proses pendidikan haruslah tetap memberikan kesempatan yang cukup kepada mahasiswa untuk belajar dalam mengasah keterampilan klinisnya. ${ }^{2,4}$ Atas dasar inilah, proses pembelajaran keterampilan klinis berkembang dengan menggunakan teknik simulasi dengan bantuan alat atau model..$^{5 \cdot 7}$

Latihan keterampilan klinis dengan semulasi menggunakan alat atau model (skill lab) dapat memenuhi dua kebutuhan dan tantangan pada pelayanan kesehatan dan pendidikan sekaligus. Latihan keterampilan pada model dapat meningkatkan keamanan dan menurunkan kesalahan yang dilakukan pada latihan dengan pasien pada tahap proses pendidikan selanjutnya. ${ }^{8-11} \mathrm{Hal}$ ini dapat dicapai karena setiap keterampilan procedural, pada tahap awal diberikan pelatihan pada mahasiswa dengan menggunakan model hingga mahasiswa telah memahami konsep dan dengan kecakapan pada level tertentu. Dengan kemampuan pada level tersebut sudah cukup aman jika dilakukan proses latihan pada pasien dengan supervisi. Pelatihan keterampilan klinis dengan simulasi menggunakan alat juga telah terbukti mampu meningkatkan kecakapan mahasiswa mulai dari keterampilan sederhana hingga yang lebih kompleks, ${ }^{11,13}$ pelatihan keterampilan klinis meningkatkan komptensi mahasiswa pada kepaniteraan klinik. ${ }^{14,15}$

Melihat pentingnya peranan skill lab dalam pendidikan kedokteran saat ini, maka pelaksanaannya harus dilaksanakan dengan sebaik mungkin. Fakultas Kedokteran Universitas Andalas (FK-Unand) Padang telah melaksanakan pendidikan keterampilan klinis melalui skill lab sejak tahun 2004 seiring dengan terjadinya perubahan paradigma dan sistim pembelajaran di kedokteran menjadi kurikulum berbasis kompetensi dengan metode PBL (Problem Based Learning). Oleh karena itu, penelitian evaluatif sangat perlu dilakukan secara berkala dan pada semua aspek pelaksanaanya. Pada penelitian ini dilihat bagaimana pandangan mahasiswa terhadap pelaksanaan dan hambatan yang dalam pencapaian kompetensi yang diharapkan. Penelitian ini diharapkan tidak hanya memberikan masukan untuk perbaikan pelaksanaan skill lab di FK-Unand tapi juga pada pendidikan kedokteran di Indonesia pada umumnya.

\section{METODE}

Penelitian dilakukan pada bulan Agustus 2012 sampai dengan Januari 2013 di Fakultas Kedokteran Universitas Andalas, dengan disain penelitian kualitatif untuk menjawab pertanyaan yang lebih mendalam.

Responden dipilih secara purposif, yakni mahasiswa pada Semester V dan VII (tahun III dan IV). Pemilihan mahasiswa tahun III dan IV ini adalah untuk mendapatkan respon yang lebih lengkap dari mahasiswa tersebut karena mahasiswa ini sudah melewati sebagian besar tahapan pendidikan preklinik dan pelatihan pada hampir semua modul skill lab. Perekrutan responden dilakukan secara terbuka dan bersifat sukarela. Semua mahasiswa tahun III dan IV diberitahukan dan diundang secara terbuka kesediannya untuk menjadi responden penelitian. Ada 46 mahasiswa menyatakan kesediannya sebagai responden untuk penelitian.

Pengumpulan data dilakukan dengan wawancara mendalam perorangan. Setiap mahasiswa dilakukan 
wawancara selama 20-40 menit terkait dengan tujuan penelitian tentang pengalaman mereka selama mengikuti proses pendidikan latihan pada skill lab. Materi wawancara fokus pada tiga aspek utama pada pelaksanaan skill lab, yakni kesesuaian materi skill lab dengan blok yang sedang berjalan, alokasi waktu pelaksanaan dan hambatan dalam pelaksanaan dan pencapaian kompetensi yang diharapkan. Selanjutnya, data-data diolah dan dianalisa secara tematik

\section{HASIL DAN PEMBAHASAN}

Sebagian besar mahasiswa berpendapat bahwa materi pada modul skill lab sudah sesuai dengan peta kurikulum dan sejalan dengan blok yang sedang dipelajari (diagram 1). Meskipun demikian, masih terdapat beberapa materi yang dirasakan tidak relevan dengan modul yang sedang berjalan, yaitu pemeriksaan obstetri pada blok gangguan hormon dan metabolisme dan journal reading pada block neuropsikaitri.

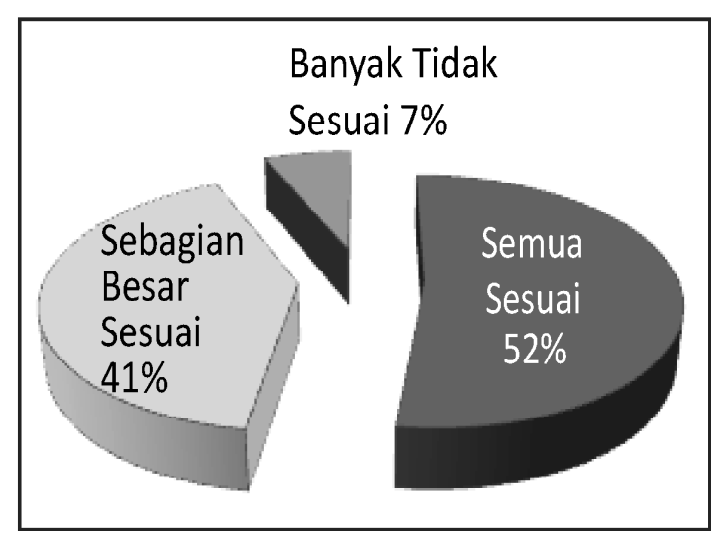

Digaram 1. Pandangan mahasiswa terhadap kesesuai materi skill lab dengan peta kurikulum

Materi yang dipelajari pada skill lab juga tidak dirasakan sulit oleh sebagian besar (59\%) mahasiswa (diagram 2). Namun ada mahasiswa (41\%) yang merasakan kesulitan dalam memahami dan mempelajari beberapa materi yang sebenarnya tidak langsung berkaitan dengan dengan materi skill lab, tapi lebih terkait dengan teknis (R1, 5, 6, $7,12,1430,39)$ dan kurangnya waktu bimbingan (R17, 19, 15, 28). Sebagaimana yang disampaikan oleh mahasiswa:
"JVP sulit, tapi tergantung instruktur skill lab. Ada instruktur yang benar-benar menjelaskan pada mahasiwa, bahkan mahasiswa diminta untuk mmbuat gambar. Tetapi ada juga beberapa instruktur tidak begitu menjelaskan, sehingga mahasiswa tidak mengeti dengan baik" (R7).

"Keterampilan pemeriksaan fisik perkusi paru, tidak dapat membedakan karena memang harus dicobakan pada kasus atau pasien yang sebanarnya" (R14).

"Sebenamya tidak sulit juga, tetapi waktu untuk diskusi dengan instruktur tidak cukup sehingga kurang dimengerti" (R17).

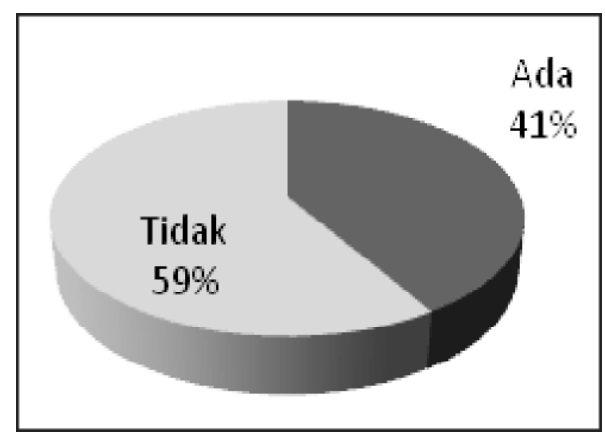

Diagram 2. Pandangan mahasiswa terhadap adanya kesulitan materi

Struktur dan sistematika penulisan petunjuk skill lab sudah dirasakan baik oleh sebagian besar (80\%) responden, namun sebagian kecil (20\%) masih merasakan adanya kekurangan dari sistematika penulisan (lihat diagram 3). Dari sebagian kecil kekurangan sistematika penulisan yang disampaikan adalah adanya beberapa panduan skill lab dengan bahasa yang kurang bagus dan terlihat seperti terjemahan dari bahasa Inggris yang kurang cocok

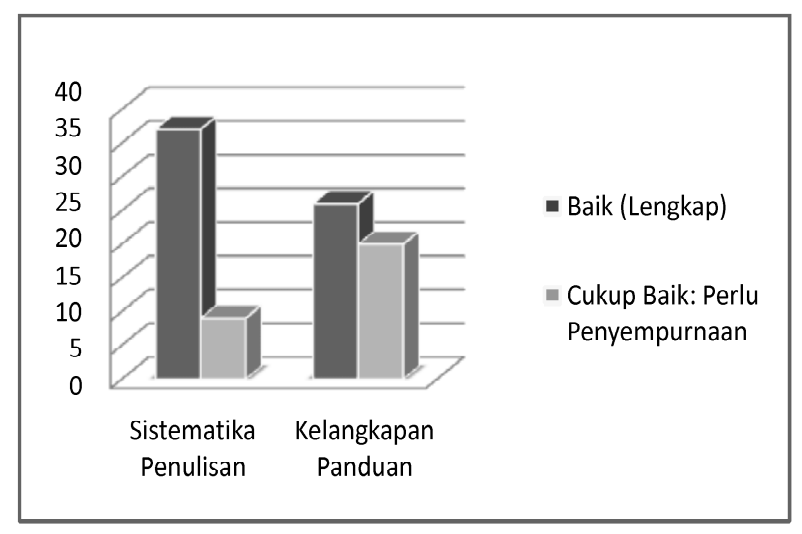

Pandangan mahasiswa 3. Respon mahasiswa terhadap sistematika penulisan dan kelengkapan panduan skill lab 
Namun respon mahasiswa terhadap kelengkapan penuntun skill lab hampir sebanding antara yang menyampaikan cukup baik (56\%) dan kurang (44\%) (diagram 3). Kekurangan kelengkapan dalam panduan tersebut terutama kecukupan dan kualitas gambar serta tidak adanya video pendukung.

Alat dan sarana pembelajaran dirasakan sangat membantu oleh semua mahasiswa dalam proses pembelajaran, namun semuanya juga merasakan alatalat tersebut sangat kurang, yang tidak sebanding dengan jumlah kelompok mahasiswa yang belajar terstruktur. Hal ini akan menjadi lebih terasa lagi bila ada alat-alat yang rusak atau kurang baik ataupun adanya perubahan jadwal. Dengan kekurangan alat ini, sangat sulit untuk melakukan belajar kelompok tidak terjadwal (belajar mandiri) diluar jadwal yang ada.

Sama halnya dengan kecukupan alat, alokasi waktu untuk kegiatan skill lab juga dirasakan kurang oleh sebagian besar (78\%) mahasiswa (diagram 4). Pada beberapa modul yang jenis skill banyak pertemuan satu kali seminggu dirasakan kurang. Seperti disampaikan oleh mahasiswa:

“...sebaiknya satu topik skill lab [dilaksanakan] dua kali pertemuan, yang pertama penjelasan materi dan latihan, yang kedua khusus latihan, baru pada pertemuan yang ketiga untuk ujian" (R24).

"Waktu belum cukup, terkadang bimbingan hanya satu kali pertemuan tiap materi, yang [harus] dipahami banyak sekali sehingga skill yang diharapkan tidak tercapai" (R25).

"Ada beberapa materi latihan skill lab yang terlalu padat, sehingga waktu dua minggu untuk latihan dan ujian dirasakan tidak cukup" (R40).

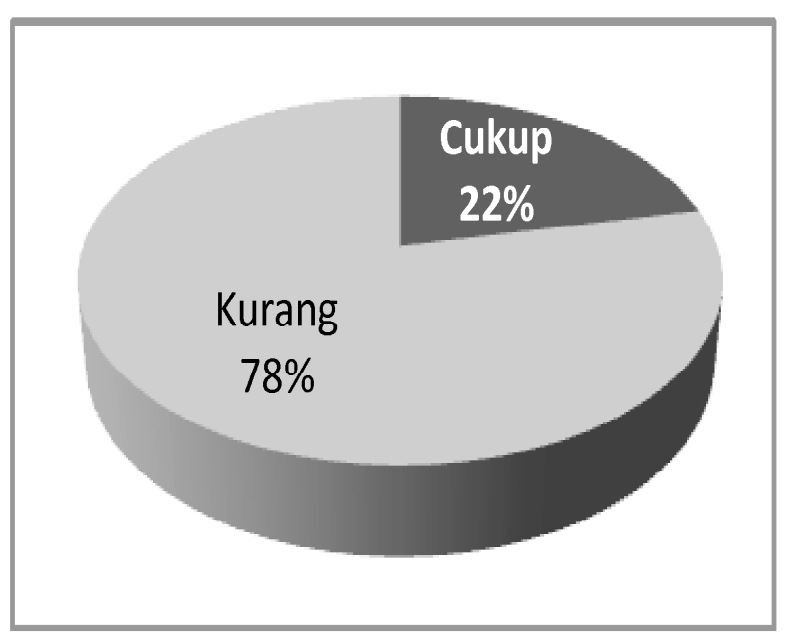

Diagram 4. Alokasi waktu untuk kegitan skill lab terjadwal

Hambatan dalam pelaksanaan skill lab yang dialami mahasiswa terutama disebabkan oleh kehadiran dosen instruktur yang tidak tepat waktu ataupun penggantian jadwal dengan alokasi waktu yang tidak sesuai (tabel 1). Diantaranya mahasiswa menyampaikan:

"Sebenarnya [alokasi waktunya] cukup, namun banyak penundaan waktu dan penggantian waktu oleh instruktur yang tidak sesuai" (R4).

"Waktunya sudah cukup kalau instrukturnya datang tepat waktu" (R23).

"Waktu untuk bimbingan sebenarmya cukup, namun instruktur lebih sering terlambat atau tidak datang sama sekali, kemudian menggabungkan tiga skill lab dalam satu pertemuan" (R30).

Selain itu juga faktor instruktur terdapat faktor-faktor lain yang menjadi hambatan mahasiswa mendapatkan pengalaman belajar dan mencapai kompetensi yang diharapkan, seperti kurangnya peralatan, tidak adanya panduan audio visual dalam setiap skill lab dan alokasi waktu yang kurang, selengkapnya yang terlihat pada tabel 1. 
Tabel 1. Hambatan dalam proses pembelajaran

\begin{tabular}{|c|c|c|c|}
\hline \multirow{2}{*}{ Tema } & \multirow{2}{*}{ Subtema } & \multicolumn{2}{|c|}{ Jumlah $(\mathrm{N}=46)$} \\
\hline & & f & $\%$ \\
\hline \multirow[t]{6}{*}{ Instruktur } & Instruktur tidak tepat waktu & 20 & $43.48 \%$ \\
\hline & Kesamaan persepsi instruktur kurang & 20 & $43.48 \%$ \\
\hline & Instruktur memindahkan jadwal & 11 & $23.91 \%$ \\
\hline & Kompetensi instruktur & 9 & $19.57 \%$ \\
\hline & Instruktur yang ganti-ganti & 7 & $15.22 \%$ \\
\hline & Instruktur kurang mengajarkan & 4 & $8.70 \%$ \\
\hline \multirow{3}{*}{$\begin{array}{l}\text { Pcralatan } \\
\text { Panduan }\end{array}$} & Alat kurang & 19 & $41.30 \%$ \\
\hline & $\begin{array}{l}\text { Kurang gambar pada penuntun dan video } \\
\text { pendukung }\end{array}$ & 7 & $15.22 \%$ \\
\hline & Teori dan skill lab kurang sinkron & 5 & $10.87 \%$ \\
\hline \multirow[t]{2}{*}{ Penilaian } & Standarisasi penilaian oleh instrukur & 7 & $15.22 \%$ \\
\hline & Transparansi dan standarisasi nilai & 4 & $8.70 \%$ \\
\hline Alokasi Waktu & Alokasi waktu kurang & 6 & $13.04 \%$ \\
\hline
\end{tabular}

Pada faktor instruktur tersebut, 43,48\% mahasiswa melaporkan kehadiran instruktur yang sering tidak tepat waktu merupakan hambatan tersebut. Hambatan lain dari faktor instruktur adalah tidak adanya kesamaan persepsi dan teknis skill diantara instruktur yang dilaporkan oleh 43,48\% mahasiswa, sehingga ilmu yang didapatkan oleh mahasiswa yang berbeda juga berbeda antara satu kelompok dengan yang lainnya. Hambatan lain dari faktor instruktur juga akibat seringnya penggantian jadwal $(23,91 \%)$, konpetensi instruktur yang kurang $(19,57 \%)$, instruktur yang kurang mengajarkan (8,7\%), dan seringnya instruktur berganti $(15,22 \%)$ (tabel 1). Semua kondisi ini sangat erat kaitannya dengan kesibukan instruktur yang ditunjuk, sehingga menyebabkab kehadiran yang tidak tepat waktu atau jadwal yang diganti ataupun digantikan oleh instruktur lain yang kurang kompeten pada skill tersebut. Sebagaimana yang diungkapkan oleh mahasiswa:
"Kemampuan, kompetensi, serta persepsi setiap instruktur berbeda-beda, harus disamakan. Lalu orang-orang yang dipilih menjadi instruktur memang yang kompeten dan memiliki waktu untuk kegiatan skill lab sesuai dengan jadwal yang sudah ditetapkan" (R8).

"...kadangkadang instruktur berbeda-beda kompetensi sehingga mahasiswa bingung ilmu yang benar itu yang mana" (R14).

“...sulit sekali mencocokkan jadwal skill lab dengan instruktur yang sangat sibuk, akibatnya pertemuan tidak optimal" (R24).

Penelitian ini menunjukkan hambatan untuk mendapatkan proses pembelajaran optimal dan pencapaian kompetensi yang diakibatkan oleh beberapa faktor, seperti alokasi waktu yang kurang, sarana pembelajaran yang tidak memadai dan faktor instruktur. Secara skematis dapat dijelaskan dengan diagram 5 . 


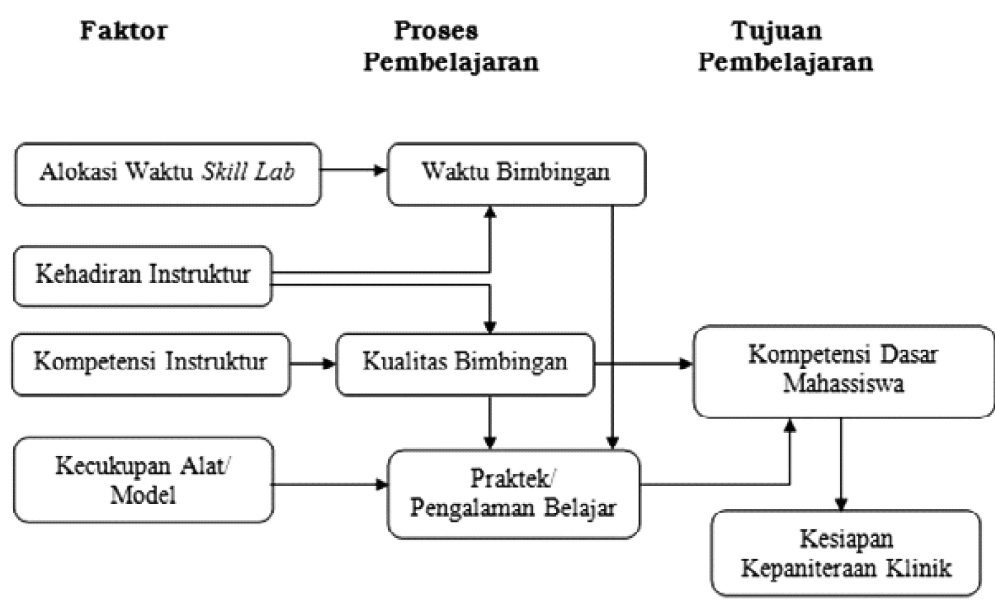

Diagram 5. Faktor-faktor yang mempengaruhi pencapaian pengalaman belajar dan kompetensi mahasiswa

Meskipun tidak menjadi faktor hambatan utama, pada beberapa modul skill lab alokasi waktu yang dijadwalkan dirasakan kurang untuk mendapatkan pengalaman belajar yang optimal. Pertemuan untuk setiap satu jenis keterampilan tidak dapat diseragamkam menjadi dua kali. Pada keterampilan klinis yang lebih komplek memerlukan waktu yang lebih lama untuk mempelajarinya sehingga tidak dapat hanya diajarkan dan dipraktekkan dengan satu atau dua kali pertemuan saja untuk mencapai level kompetensi yang sama. Sebagaimana yang dilaporkan Montgomery ${ }^{16}$, bahwa frekuensi dan waktu latihan sangat menentukan dalam pencapaian kompetensi.

Faktor kekurangan sarana pembelajaran juga menjadi hambatan yang dialami oleh mahasiswa. Faktor ini termasuk mencakup kecukupan alat dan sarana multi media seperti video untuk pelatihan keterampilan sangat penting untuk mendapatkan pengalaman belajar yang optimal. Tanpa peralatan yang memadai proses belajar pada skill lab tidak dapat dilakukan secara optimal untuk mencapai tujuan pembelajaran atau kompetensi yang diharapkan, karena pada intinya model dan peralatan tersebut yang membedakan proses pembelajaran skill lab dengan perkuliahan ataupun dengan tahap klinis dengan pasien. Begitu juga halnya dengan sarana multimedia (video) untuk pelatihan skill labyang dapat meningkatkan efektifitas proses pembelajaran. ${ }^{17,18}$ Studi lain juga menyebutkan bahwa adanya peralatan yang memadai yang didukung oleh instruksi dan media pembelajaran dengan video akan meningkatkan kompetensi di- bandingkan instruksional pembelajaran standar. ${ }^{19}$

Faktor instruktur menjadi hambatan utama bagi mahasiswa dalam pembelajaran skill lab. Faktor-faktor tersebut adalah kehadirannya yang tidak tepat waktu, penggantian jadwal dengan alokasi yang tidak sesuai, instruktur pengganti yang kurang kompeten, dan kurang memberikan penjelaskan tentang keterampilan yang diajarkan. Secara bersama-sama, semua aspek pada faktor instruktur tersebut akan menurunkan waktu bimbingan, kualitas bimbingan yang diberikan pada mahasiswa dan proses pembelajaran yang dilakukan. Akhirnya tujuan pembelajaran dan kompetensi yang diharapkan tidak dapat dicapai, seperti yang terlihat pada diagram 5 . Keberadaan dan kehadiran instruktur tidak dapat digantikan intruksional pembelajaran dengan multi media terutama untuk mengajarkan jenis keterampilan klinis yang kompleks. ${ }^{20}$ Keterampilan klinis memerlukan penjelasan implikatif (reasoning) pada setiap prosedur yang dilakukan. Bila kehadiran dan kecakapan instruktur disertai dengan multimedia menjadikan proses pembelajaran sangat efektif dan mampu meningkatkan kompetensi mahasiswa dengan daya ingat yang lebih baik. ${ }^{21}$

\section{KESIMPULAN}

Hambatan dalam proses pembelajaran dan pencapaian kompetensi yang diharapkan yang dirasakan mahasiswa adalah permasalahan pada dosen instruktur, peralatan yang tidak mencukupi, dan alokasi waktu yang kurang. 
Diantara faktor-faktor tersebut, hambatan utama adalah permasalahan dosen instruktur, yaitu kehadiran yang tidak tepat, penggantian jadwal dengan alokasi waktu yang tidak sesuai, dan instruktur pengganti yang kurang kompeten. Akibatnya mahasiswa tidak mendapatkan pembelajaran dan praktik keterampilan yang cukup.

Oleh karena itu, untuk mengatasi permasalahan atau hambatan ini, penataan skill lab harus dilakukan secara menyeluruh yang tidak hanya dengan mencukupi peralatan dan fasilitas. Lebih dari itu, penataan sistim dan sumber daya manusia (dosen) dengan menghitung beban kerja setiap sangat perlu dilakukan. Penelitian lebih lanjut sangat perlu dilakukan untuk menilai secara lebih rinci terhadap kekurangan fasilitas, kehadiran instruktur dan alokasi waktu bimbingan.

\section{Izin Penelitian dan Etika}

Mahasiswa sebagai responden pada penelitian ini dengan sukarela dan menyetujui secara tertulis untuk berpartisipasi. Pelaporan data dan hasil penelitian dilakukan secara anonim yang mana nama-nama individu responden tidak disebutkan dan tidak dapat diidentifikasi. Penelitian ini mendapatkan izin dari Dekan Fakultas Kedokteran Universitas Andalas, dan tidak ada konflik kepentingan dalam penelitian dan penulisan laporan penelitian ini.

\section{DAFTAR PUSTAKA}

1. Boursicot K, Truchie R. Setting standards in a professional higher education course: defining concept of the minimally competent student in performance-based assessment at the level of graduation from medical school. Higher Education Quarterly. 2006;60(1):74-90.

2. Dent JA, Harden RM. New horizon in medical education. In: Dent JA, Harden RM, editors. A Practical Guide for Medical Teachers. 2nd ed. London: Elsevier-Churchill Livingston; 2005. p. 2-8.

3. Goodwin J. The importance of clinical skills. BMJ [serial on the Internet]. 1995; 310(1281): Available from: www.bmj.com/content/310/6990/1281.

4. Peterson MJ, Bechtel GA. Combining the arts: An applied critical thinking approach in the skills laboratory. Nursing Connection. 2000;13(2):43-9.

5. Neary M. Project 2000 students' survival kit: a return to the practical room (nursing skills laboratory) Nurse Education Today. 1997;17(1):46-52.
6. Studdy SJ, Nicol MJ, Fox-Hiley A. Teaching and learning clinical skills, Part 1: Development of multidisciplinary skills centre. Nurse Education Today. 1994;14(3):177-85.

7. Studdy SJ, Nicol MJ, Fox-Hiley A. Teaching and learning clinical skills, Part 2: Development of multidisciplinary skills centre. Nurse Education Today. 1994;14(3):186-93.

8. Ziv A, Ben-David S, Ziv M. Simulation based medical education: an opportunity to learn from errors. Medical Teacher. 2005;27(193-199).

9. Barrows HS. An overview of the uses of standardized patients for teaching and evaluating clinical skills. Academic Medical Journal Association of American Medical Colleges. 1993;68:443-51.

10. Bradley P, Postlethwaite K. Setting up a clinical skills learning facility. Medical Education. 2003;37(Suplement 1):6-13.

11. Issenberg SB, McGaghie WC, Petrusa ER, LeeGordon D, Scalese RJ. Features and uses of highfidelity medical simulations that lead to effective learning: a BEME systematic review. Medical Teacher. 2005;27:10-28.

12. Lynagh M, Burton R, Sanson-Fisher R. A systematic review of medical skills laboratory training: where to from here? Medical Education. 2007;41:879-87.

13. Khan K, Pattison T, Sherwood M. Simulation in medical education. Medical Teacher. 2011;33:1-3.

14. Barsuk JH, McGaghie WC, Cohen ER, Balachandran JS, Wayne DB. Use of simulation-based mastery learning to improve the quality of central venous catheter placement in a medical intensive care unit. Journal of Hospital Medicine. 2009;4:397-403.

15. McGaghie WC, Draycott TJ, Dunn WF, Lopez CM, Stefanidis D. Evaluating the impact of simulation on translational patient outcomes. Simulation in Healthcare. 2011;6(Suplement):S42-S7.

16. Montgomery C, Kardong-Edgren SE, Oermann MH, Odom-Maryon T. Student satisfaction and self report of CPR competency: Heart code BLS courses, instructor-led CPR courses, and monthly voice advisory manikin practice for CPR skill maintenance. International Journal of Nursing Education Scholarship 2012.

17. Shippey SH, Chen TL, Chou B, Knoepp LR, Bowen CW, Handa VL. Teaching subcuticular suturing to medical students: video versus expert instructor feedback. Journal of Surgical Education. 2011;68(5):397-402.

18. Smith AR, Cavanaugh C, Moore WA. Instructional multimedia: an investigation of student and instructor attitudes and student study behavior. BMC Medical Education. 2011;11(38). 
19. Braslow A, Brennan RT, Newman MM, Bircher NG, Batcheller AM, Kaye W. CPR training without an instructor: development and evaluation of a video selfinstructional system for effective performance of cardiopulmonary resuscitation. Resuscitation. 1997;34(3):207-20.

20. Bjerrum AS, Hilberg O, van-Gog T, Charles P, Eika B. Effects of modelling examples in complex procedural skills training: a randomised study. Medical Education. 2013;47(9):888.

21. Isbye DL, Høiby P, Rasmussen MB, Sommer J, Lippert FK, Ringsted C, et al. Voice advisory manikin versus instructor facilitated training in cardiopulmonary resuscitation. Resuscitation. 2008;79(1):73-81. 